\title{
PPP for Metro Project: A Case Study of Hyderabad Metro
}

\section{Darshit Mehta, Jagath Kumari Dungi}

\begin{abstract}
The new metro rail policy was enacted by the government of India in the year 2017. Under this policy, under section xiv, the Government of India (GOI) made it compulsory to seek Public-Private Partnership (PPP) for metro projects which are intending to seek financial assistance from the central government. Hyderabad Metro is by far the largest metro project to be executed under PPP, but is it successful? This paper investigates various factors that affected the timeline of the Hyderabad metro. It evaluates various aspects in the preconstruction, construction, and post-construction phase of the Hyderabad metro. Finally, suggestions are made in the form of conclusions that would increase the likelihood of a successful $P P P$ in the metro.
\end{abstract}

Keyword: Public Private Partnership, Hyderabad Metro, Metro Project, New Metro Rail Policy

\section{INTRODUCTION}

Government of India under its new Metro Rail Policy, 2017 set up the need for PPP in metro projects. The Policy under section 14, subsection b stated, "Government will encourage Public-Private Partnership (PPP) for implementation of the metro rail projects in the country. State Government desirous of availing central financial assistance for a metro rail system in a city should mandatorily explore the possibility of having a PPP arrangement". The Policy also stated four common methods of financing a metro project. These include 50:50 joint venture, this method was adopted in a metro project like Mumbai Line-3, Chennai, Bangalore, Nagpur, Lucknow, Kochi, and Ahmedabad. The second model is full funding of the metro project by the central government, and these include the Kolkata metro project and East-West corridor in Kolkata. The third model is that of complete funding by the state government and includes Jaipur metro and monorail project in the city of Mumbai. The fourth model is of Public-Private Partnership (PPP) and it has been implemented in Hyderabad metro, Mumbai Metro Line-1, and the Rapid Metro in Gurugram.

Manuscript received on May 18, 2021

Revised Manuscript received on July 09, 2021.

Manuscript published on July 30, 2021.

* Correspondence Author

Darshit Mehta*, Post Graduate Student, Department of Civil Engineering and Management, School of Architecture and Planning, Vijayawada (Andhra Pradesh), India.

Jagath Kumari Dungi, Assistant Professor, Department of Architecture, School of Architecture and Planning, Vijayawada (Andhra Pradesh), India.

(C) The Authors. Published by Blue Eyes Intelligence Engineering and Sciences Publication (BEIESP). This is an open access article under the CC BY-NC-ND license (http://creativecommons.org/licenses/by-nc-nd/4.0/)
India's rapid urbanization is also one of the reasons as to why there is a rapid shift to MRT based public transport. As of census 2011, about 377 million Indians making up $31.14 \%$ of the country's population lived in urban areas. This urban population is projected to grow by 600 million (40\%) by 2031 and 850 million (50\%) by 2051 [3]. While urban population increases productivity and urban population improves GDP per capita, it is estimated that India will be generating 70\% of its GDP by 2030 through urban population. Estimate by government organizations suggest that an investment of $\$ 1.2$ trillion would be required in a span of 20 years to keep up with the demands of the growing population. There is a vast difference in the amount of money to be spent by the government versus the amount that is needed to be spent. This difference can be understood from the fact that India requires to spend \$134 per capita to meet the urbanization needs of the country while the country spends around \$20 per capita for urbanization. Urbanization includes a lot of programs like housing, slum eradication, sanitation, drainage etc. we cannot overlook the fact that effective public transport is an important need for urbanized India. It has been discovered that there is a decline in public transit, also half of all city drivers spend more than 12 hours a week stuck in their car [4].

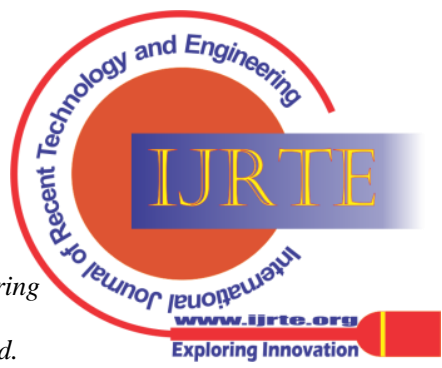




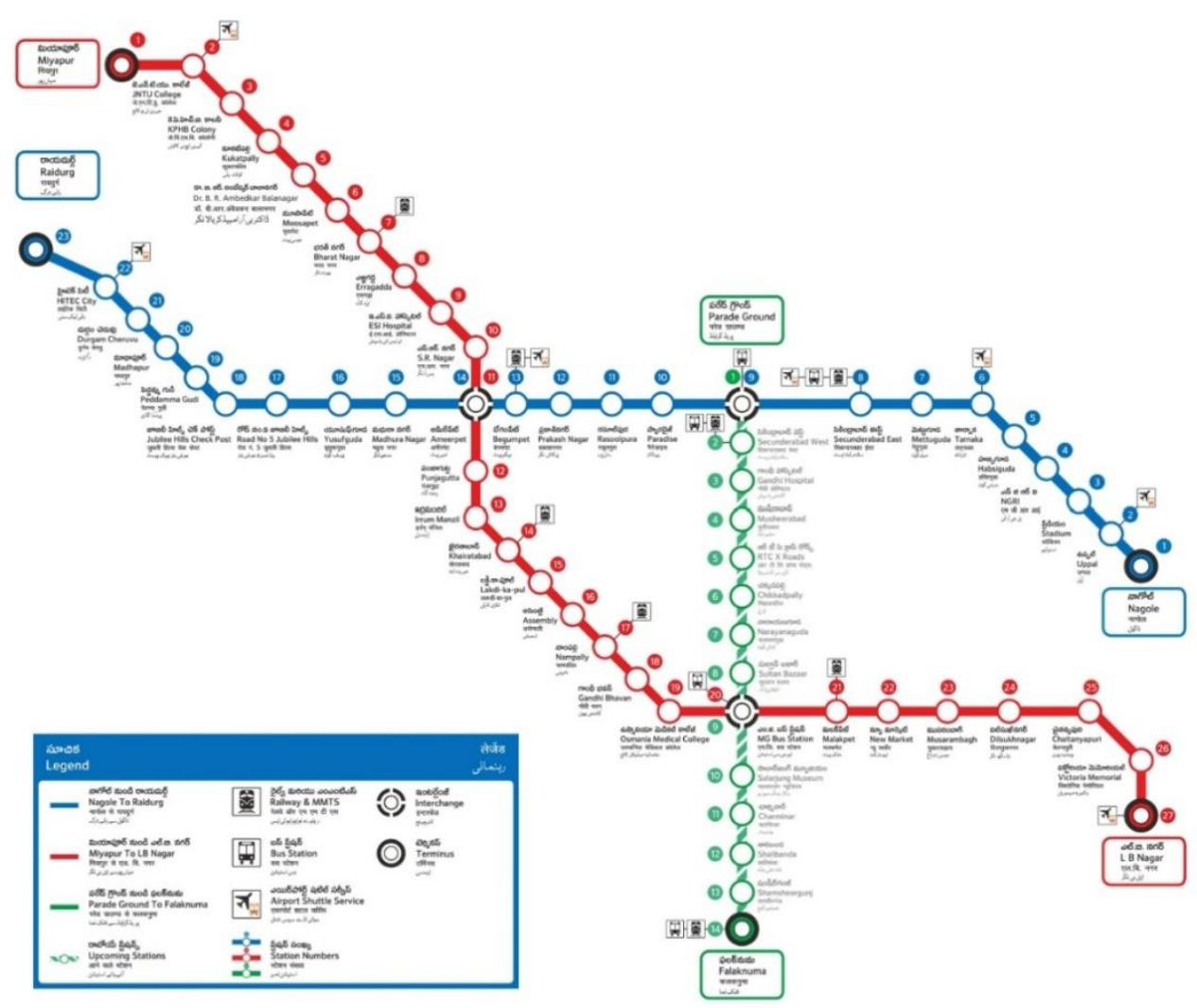

Figure 1: - Route Map of Hyderabad Metro (Source: Hyderabad Metro Rail website)

\section{METHODOLOGY}

The research looks into various problems faced during the execution of Hyderabad Metro. It will draw relevant information that can be used as steppingstones for further metro projects under PPP. To get an insight to the metro project in Hyderabad, various research papers, annual reports, memorandum, newspaper articles etc. are referred to conclude various obstacles in the Hyderabad Metro and their impact on the popularity of PPP projects for metro rail.

\section{INTRODUCTION}

The first contract under PPP was awarded to a consortium of two real estate companies, Navbharat, and Maytas Metro Limited (MML) on 19 September 2008. The earlier consortium did not seek any Viability Gap Funding (VGF) and offered a royalty of ₹30,311 cr to the Government of Andhra Pradesh (GOAP). But, a shocking revelation of the Satyam Computer, the parent company of the real estate company Maytas on 7 January turns the spotlight back on Maytas (Ramachandraiah, 2009). Because of this, the contract between Maytas and GOAP was considered void, and a new contract between L\&T and COAP was signed under Design-Build-Finance-OperateTransfer (DBFOT) system.

The metro project, as proposed by Delhi Metro Rail Corporation (DMRC), is of length of $72 \mathrm{~km}$ in phase 1 . These include,

1) Corridor 1: Miyapur-LB Nagar: 29km; 27 stations - Red Line

2) Corridor 2: JBS-Falaknuma: 15km; 15 stations Green Line
3) Corridor 3: Nagole-Raidung: 28km; 24 stations Blue Line

Financial Closure for the Hyderabad Metro was done within a record time of six months by L\&T. L\&T received a financial closure of ₹ $14,132 \mathrm{cr}$ as against the estimated cost of ₹ $12,132 \mathrm{cr}$. The Viability Gap Funding (VGF) available from the central government was ₹ $1,458 \mathrm{cr}$. The appointed date was declared as July 5, 2012, a concession period of 35 years, including five years of construction, which will be counted from the date of appointment [5].

To make the project more financially viable, real estate development is a part of the contract agreement. L\&T can do real estate development at the three depots available at Miyapur (Depot - 1), Falaknuma (Depot - 2), and Nagole (Depot - 3). This development is with an initial condition of providing a certain minimum percentage of land on ground floor solely for maintenance and stabling of metro while the space above the ground floor can be exploited for real estate. Similarly, $20 \%$ of the floor area of each metro station can be used for Real Estate Development; however, any such development can be made over the parking or circulation areas [6]. The approximate area for real estate development is 269 acres.

The development of real estate is not a new concept; this model is successfully implemented in the Hong Kong metro, which is among the few metros that have been successful under PPP model.

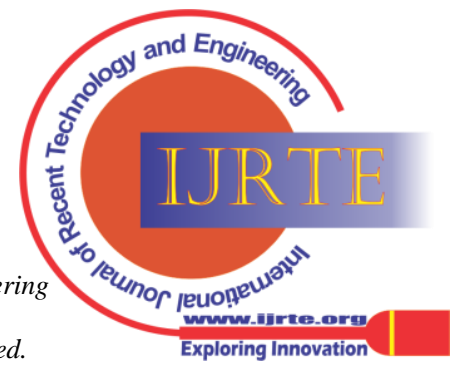


A study by Imperial College, London identified Rail + Property as the fundamental reason for the success of Hong Kong's MTR [7]. While MTR or Mass Transit Railway allocates property rights to the operator to subsidize railway building, operations, and reinvestment [7], similarly revenue from the real estate development is expected to bring the required increase in financial viability of the metro project.
This entire study is conducted based on conclusive evidence available in the public domain through various sources, this includes (but not limited to) research papers, news articles, annual reports, interviews, video lectures etc. Also, some analysis is done by comparing the PPP project of the Mumbai metro, Singapore metro, and Hong Kong metro. However, this research is limited to sources that are available in Black \& White.

\section{RESEARCH METHODOLOGY}

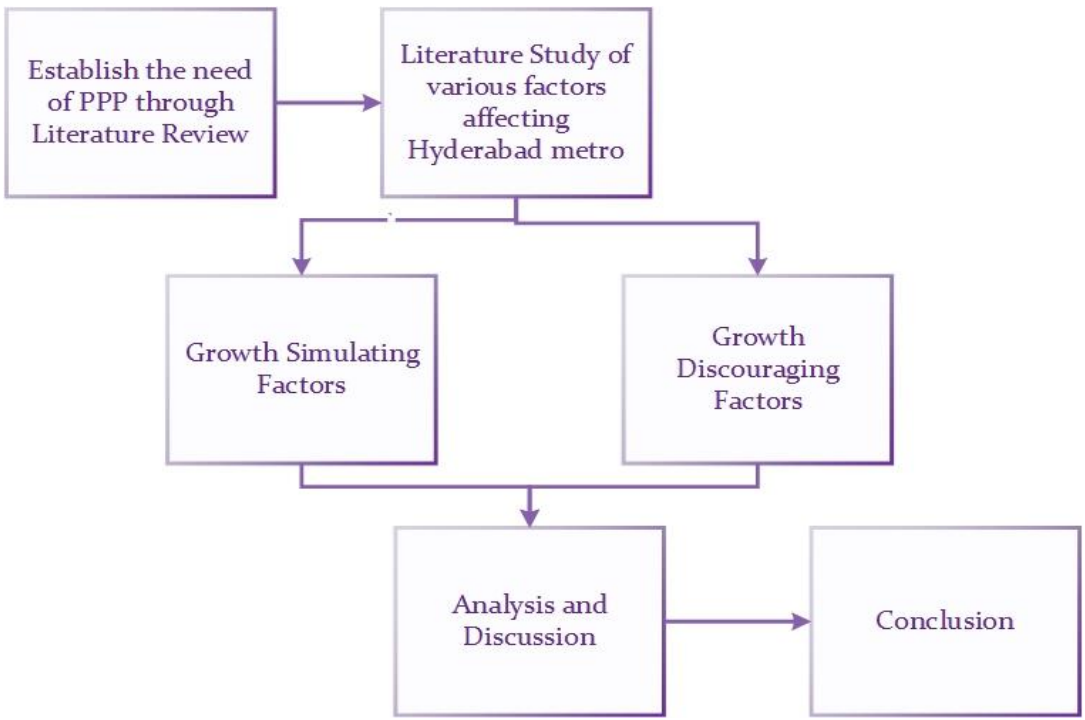

Figure-2: Research Methodology (Source: Author)

\section{Analysis and Discussion [8] [9] [10]:}

This section of research gives an insight into stimulating and discouraging factors for the Hyderabad Metro project at three different stages namely Pre-Construction, Construction and Post Construction stage.

Pre-Construction: During Pre-Construction, the stimulating factors for the metro project included the encouragement of PPP through policy support by the Government of India, the support from Government of Andhra Pradesh (GOAP) for the project even after the failure of Maytas Group. This form of government support helped to keep the project alive. Support in the form of regulations was well received from GOAP and was clear when the Andhra Pradesh Municipal Tramways Act was passed in the year 2008. Furthermore, financial closure for the project was obtained by L\&T from a consortium of 10 banks of ₹ 14,132 crs. A well-structured PPP agreement was made for the said project and this allowed the concessionaire to change the fair structure after providing the notice to the government. This kind of independence of fare structure is important for the private, as we see that there were problems in the Mumbai Metro in the case of fare structure revision [11].

While these were the factors that helped the metro, there were certain other factors that caused a hindrance to smooth execution of the metro. One such factor in pre-construction is the Satyam scam. When Satyam scam surfaced, Maytas procured the PPP project for Hyderabad metro. This scam raised the uncertainty about the idea of PPP since the first concessionaire had defaulted even before the start of the which is a daughter company of Satyam had already

project. Placing of the piers inside the university campus of Osmania University at Tarnaka because of the separate statehood agitation that was at peak during that time. Similar changes were to be made for the corridor two from Jubilee Bus Station to MGBS, where the original plan was to build an overhead station with exclusive skywalk for the students. This required placing of piers inside the campus, however, $\mathrm{t}$ his too was changed owing to the political climate at that time [12]. Similarly, lack of detailed drawings for underground utilities was one of the challenges before the start of the construction of the Hyderabad Metro.

Construction: During the construction phase, good governance was seen which helped in speedy decision making and solving the problems related to the project. Furthermore, in the year 2014 the central government changed which led to generation of stable economics as in the previous government the inflation reached in double digits.

During construction, the state of Andhra Pradesh divided into two states of Telangana and Andhra Pradesh. This created a cloud of political uncertainty for the project. Change in the state government was another challenge, since in 2015-2016, the new government asked for the change in alignment at some of the locations [13]. Other challenges during construction included the availability of continuous right of way, property acquisition changes, and lack of coordination between some civil agencies.

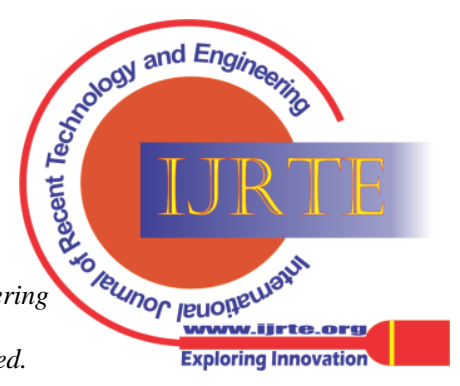


There is a gap between the execution of metro projects and the preparation of DPR, during this period there are new buildings, infrastructure that comes up and the working assumption for metro changes. Similarly, there are no drawings of underground utilities from the Nizam's time, which is again a challenge for smooth construction of the metro project [14].

Post Construction: The project incorporates various features like smart cards, free water, parking facilities, bicycle facilities etc. to provide end-to-end connectivity and increase the comfort level of the passengers.

While a part of the project went operational in the year 2017, the achieved ridership was way less than the estimated ridership. The ridership on April 27, 2019, was around 2.55 lakhs passengers per day while the planned ridership for the year 2017 was around 17 lakhs per day [15]. But one point that should be noted is by the year all the three phases of the metro were planned to be operational. As of February 2020, passenger per day which is again less than the estimated ridership of metro [16]. Along with this, the growth of the city along the peripheral areas is again one of the challenges that the metro hold. The difference in time between the planning of the metro and the execution of the metro has led to several of these problems [15]. Also, time and cost overrun are another challenge. Increase in cost would post a challenge because of the limited funds available with the private sector. For the annual report of financial year 20192020 , L\&T post a cost overrun of ₹ 3,765 crores [17].

\section{DISCUSSION}

It is evident that the Hyderabad metro took several concepts from some of the selected metro projects like Hong Kong metro, Singapore metro, Tokyo metro and Taipei metro. While the metro aims at developing revenue through real estate as can be seen in Hong Kong metro [7] and Tokyo metro, this is also one of the concerns that has led to several agitation by various groups. Unlike Hong Kong metro, the ownership in case of Hyderabad Metro is largely by the private player. The contract includes a concession period of 35 years with a provision of extension by another 25 years. This in total can mean leasing of government owned lands to a private player for 60 years. Unlike Hyderabad metro, in Hong Kong metro, $75 \%$ of the ownership is with the government, which should be taken in notice.

Alike Singapore metro, Hyderabad metro also aims at providing last mile connectivity. Hyderabad metro provides last mile connectivity with various alternatives like smart bikes, PEDL, bounce, Zoomcar, Drivezy, Vogo, Rapido, Zify, OLA and RAYD [18]. Passenger can book an OLA while in metro and pay for the metro ticket using OLA money. Singapore metro under its non-metro operations involve operation of buses, taxis, advertising, commercial business, engineering services and other services [19].

One point to be noted is that while the idea of property development is inspired by Hong Kong metro, the success for the same does not necessarily apply to the Hyderabad Metro. This is because unlike Hyderabad metro, Hong Kong metro plans the future development of the city. For e.g., the the ridership for Hyderabad metro reached near five lakhs

LOHAS park is planned and executed by HMR, the entrances and the commercial activity around the same is planned and developed by HMR [7]. This is not the case with the Hyderabad Metro, in Hyderabad metro, the metros are built in places where there is a huge population. There are chances that while the metro is planned and executed, there is a change in the city's growth pattern leading to inefficient use of metro services. The same is seen in case of Hyderabad metro [15].

It is evident that real estate development along the metro route is an important parameter to make PPP projects financially viable, however, the ownership of the metro can be improved. Like other countries, government is the primary owner of the metro project. This kind of ownership dissolves the agitation on government land given to a private player for exploitation. Also, the DPR for Hyderabad metro was kept hidden by the government even after application of various RTI. The state government refused to disclose any such information with the fear of disclosing some vital information which is of high commercial value [20].

Later when the same information was disclosed to the public through the means of press conference, several objections were raised based on the alignment of metro [21]. This makes a clear warning that metro projects under the flagship of PPP, should be available to the public before execution. This will help in proper planning of the project and prevention of objections thereby reducing the time loss in legal proceedings.

Even though the Hyderabad metro project was expected to be completed in the year 2017, the work for corridor 2 form MCBS station and Falaknuma is still not started as on March 2020 [22]. Obtaining Right of Way for the project is the biggest hurdle so far. In an Interview with the Urban Transport News, KVB Reddy, MD \& CEO, L\&T Metro Rail Hyderabad Ltd pointed out the difficulty in the execution of Hyderabad Metro. Among continuous right of way, certain other difficulties include absence of a comprehensive underground map of utilities, absence of standardization of technical specification for metro and lengthy procedure for approval. The project cost increased to ₹ $21,000 \mathrm{crs}$ as against initial estimate of ₹ $14,132 \mathrm{crs}$ in 2013 [23].

While the risk for PPP is high because of uncertainty of ridership, there also exists a need for low interest funding for the project to make the project more viable and to capture more participants for concessionaire [9]. PPP projects can be a golden boon for metro projects for newly planned cities like Dholera Special Investment Region (SIR), where it is relatively easy to obtain continuous Right of Way (ROW) and map for underground utilities. The Government of India and the State Government of Gujarat should try out the possibility of developing a PPP model for metro projects in Dholera SIR. Good Governance with stable socio-economic conditions can really prove to be the driving force for new PPP models in metros.
Published By:

Blue Eyes Intelligence Engineering and Sciences Publication (C) Copyright: All rights reserved.

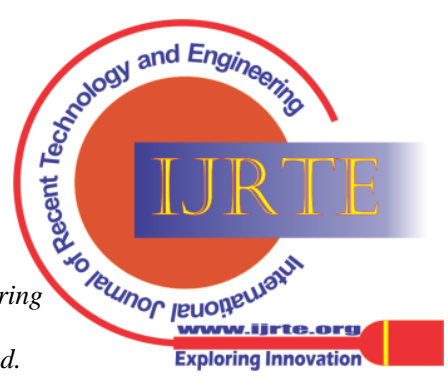




\section{CONCLUSION}

The conclusions based on this study for Hyderabad metro are as following:

- The difference between the floating of the DPR and execution of metro should be as low as possible.

- For projects like metro, it is important to consider the public feedback before executing the project to avoid delay in the form of court order or public agitation.

- Dependency on the accuracy of the ridership is must. A change in ridership is observed in all the metro projects that are built using PPP in India i.e., in Mumbai Metro, in Delhi Metro, and in the case of Hyderabad metro.

- $\quad$ Political risk can be avoided if the metro alignment is thoroughly discussed with all the stakeholders before finalizing it.

- To boost PPP projects, there is a need for low interest loans from the banks.

- The idea of PPP projects for metro with planned commercial development can work for new growing cities in India.

\section{LIMITATIONS}

A more detailed analysis is possible if people directly involved in the metro are interviewed to understand the project challenges at a micro level.

The conclusion is based on certain evidence which is evident in the present-day scenario, however, a complete picture of success/failure story of metro will be only available post execution of both the phases of metro and complete development of real estate available to L\&T Metro Rail Hyderabad Limited. Also, one of the goals of Metro rail as laid by the National Urban Transport Policy (NUTP) was to develop financial assistance to promote multi model transport system [24], since Metro is only one part of multimodel transport system, it will take time to know the final picture.

\section{REFERENCES}

1. Geetanath, V. (2018, August 17). Metro rail: the trials and tribulations of completing Corridor One. Retrieved from The Hindu: https://www.thehindu.com/news/cities/Hyderabad/metro-rail-thetrials-and-tribulations-of-completing-corridorone/article24719665.ece

2. Hyderabad Metro Rail Limited. (2016). Status. Retrieved from Hyderabad Metro Rail : https://hmrl.co.in/status.html

3. Hyderabad Metro Rail Ltd. (2010). Concession Agreement for Hyderabad Metro Rail (MRTS) Project between The Governement of Andhre Pradesh and M/s. L\&T Hyderabad Metro Rail Private Limited. Hyderabad: Hyderabad Metro Rail Ltd.

4. Imperial College London - Railway and Transport Stratergy Centre. (2017). The Operator's Story Case Study: Hong Kong SAR, China's Story. World Bank.

5. Indo-Asian News Service. (2017, November 26). Hyderabad Metro project delay by L\&T pushes up cost by over 30 per cent. Retrieved from India Today: https://www.indiatoday.in/india/story/hyderabadmetro-project-delay-by-l-and-t-pushes-up-cost-by-over-30-per-cent1094750-2017-11-26

6. Jain, D. (2020, March 17). Telangana Govt unveils Hyderabad Urban Agglomeration Project. Retrieved from Urban Transport News: https://www.urbantransportnews.com/telangana-govt-unveilshyderabad-urban-agglomeration-project/

7. Khare, A. (2020, January 17). Exclusive Interview: KVB Reddy, MD \& CEO, L\&T Metro Rail Hyderabad Ltd. Retrieved from Urban Metro News: https://www.urbantransportnews.com/exclusiveinterview-kvb-reddy-md-ceo-lt-metro-rail-hyderabad-ltd/
8. Kulshreshtha, R., Kumar, A., Tripathi, A., \& Likhi, D. (2017) Critical Success Factors in Implementation of Urban Metro System on PPP: A Case Study of Hyderabad Metro. Global Journal of Flexible Systems Management.

9. L \& T Metro Rail Hyderabad. (2018). L \& T METRO RAIL (HYDERABAD) LIMITED 8th ANNUAL REPORT FY 2017-18. Hyderabad: L \& T Metro Rail Hyderabad.

10. Last Mile Connectivity. (n.d.). Retrieved from Hyderabad Metro Rail: https://www.ltmetro.com/last-mile-connectivity/

11. Mahalakshmi, B. (2018, October 15). Hyderabad Metro, the largest PPP metro projectc, has become a big success. Retrieved from Financial Express: https://www.financialexpress.com/infrastructure/railways/hyderabadmetro-the-largest-ppp-metro-project-has-become-a-bigsuccess/1349078/

12. Nair, S. (2017, August 17). Nowhere in the world has PPP in Metro rail fully succeeded, says E Sreedharan. Retrieved from The Indian Express: https://indianexpress.com/article/india/nowhere-in-theworld-has-ppp-in-metro-rail-fully-succeeded-says-e-sreedharan4799989/

13. NK Realtors. (2018, December 28). One Year of Hyderabad Metro a Unique Succeess Story. Retrieved from N.K. Realtors (P) Ltd. https://www.nkrealtors.com/blog/one-year-hyderabad-metro-uniquesuccess-story/

14. Owens, M. G., \& Reddy, N. (2010). Hyderabad Metro Rail - A Renaissance of Urban Rail. Conference on Railway Engineering, (pp. 305-315). Wellington.

15. Ramachandraiah, C. (2009). Maytas, Hyderabad Metro and the Politics of Real Estate. INSIGHT, 36-40.

16. Rawat, V. S. (2019, November 14). Rs 3-trillion metro rail projects proposed for the next five years. Retrieved from Business Standard: https://www.business-standard.com/article/economy-policy/rs-3trillion-metro-rail-projects-proposed-for-the-next-5-years119111401510 1.html

17. SMRT Corporation Ltd . (2016). SMRT Corporation Ltd Annual Report 2016 - Twin Tracks to Performance and Growth. Singapore: SMRT.

18. Urban Transport News. (2019, April 17). Hyderabad Metro sets new standards for public transportation in India. Retrieved from Urban Transport News: https://www.urbantransportnews.com/hyderabadmetro-sets-new-standards-for-public-transportation-in-india/

19. Urban Transport News. (n.d.). Metro Rail Projects in India - At a Glance. Retrieved from Urban Transport News: https://www.urbantransportnews.com/metro-rail-projects-in-india/

\section{AUTHORS PROFILE}

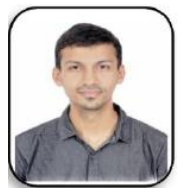

Darshit Mehta, is a post graduate student at School of Planning and Architecture, Vijayaywada. He is doing his post-graduation in Building Engineering and Management. His areas of research include Green Highway, Public Private Partnership in Metro and Time \& Cost Overrun in metro projects.

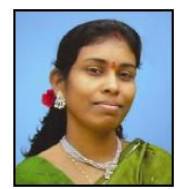

D. JagathKumari, B.E. (Civil Engineering), M.E. (SE \& NDM) D. Jagath Kumari is currently working as Assistant Professor in the department of Architecture, School of planning and Architecture, Vijayawada. Her research interest includes load carrying capacity of high-volume fly ash concrete columns and behaviour of columns subjected to high temperatures, Non-destructive testing repair, rehabilitation and restoration of structures, Green buildings and Green highway studies. 